\title{
Population dynamics of juvenile tiger prawns Penaeus esculentus in south Queensland, Australia
}

\author{
C. J. O'Brien* \\ Centre for Marine Science, University of New South Wales, PO Box 1 Kensington, Sydney, NSW 2033, Australia
}

\begin{abstract}
A 2 yr study of the prawn population on a south Queensland seagrass bed between September 1988 and September 1990 provided information on the settlement, emigration, growth and mortality of juvenile brown tiger prawns (= shrimp) Penaeus esculentus. Prawns were sampled with a beam trawl at 2 wk intervals. In 1988/89 and 1989/90 respectively, 10 and 9 cohorts of small juveniles ( 2 to $3 \mathrm{~mm}$ carapace length, CL) settled between September and July; peaks in the settlement occurred from September to November and February to March. Carapace length-frequency analysis was used to estimate the rates of growth and mortality of these cohorts. Growth of $P$. esculentus juveniles was strongly influenced by water temperature. Growth rates increased from 0.03 to $2.1 \mathrm{~mm} \mathrm{CL} \mathrm{wk}{ }^{-1}$ with increasing temperature and can be described by the equation: $G R=0.00044 \mathrm{e}^{031 T}$ where $\mathrm{GR}=$ growth rate $(\mathrm{mm} \mathrm{CL}$ $\left.w^{-1}\right)$ and $T=$ water temperature $\left({ }^{\circ} \mathrm{C}\right)$. Weekly instantaneous natural mortality rates were estimated for a maximum of $10 \mathrm{wk}$ after settlement and ranged from $M=0.06$ to 0.29 , or 5.8 to $25.2 \%$. Cohorts which settled in the summer (December to February) tended to have higher mortality rates. Overall, the mortality rates were lower than reported for other species of Penaeus and this was attributed to little fish predation due to the low natural density of $P$. esculentus and the lush seagrass cover in this area. As the mortality rates appear to be independent of water temperature and relatively low, the production of adult $P$. esculentus in the Moreton Bay fishery will be strongly influenced by the number and size of cohorts of juveniles settling in the nursery areas and their growth.
\end{abstract}

KEY WORDS: Growth $\cdot$ Length-frequency $\cdot$ Mortality $\cdot$ Penaeid $\cdot$ Population dynamics

\section{INTRODUCTION}

The juveniles of most commercial prawn species in Australia are managed by legislation which protects their nursery areas from trawling and excessive human impact. However, information on the population dynamics and the processes which influence production of juvenile prawns is scarce. Incorporating such information into management strategies should make the management of prawn fisheries more effective.

Penaeus esculentus (Haswell) is endemic to Australia and adults are fished commercially north of $30^{\circ} \mathrm{S}$. Adults and larvae usually live in stable oceanic environments (Dall et al. 1990) but postlarvae and

\footnotetext{
- Present address: CSIRO Division of Fisheries, Box 120, Cleveland, Queensland 4163, Australia
}

juveniles inhabit seagrass beds which can be subject to unstable estuarine conditions (Penn 1981, Staples et al. 1985, Coles et al. 1987, Loneragan et al. 1994). Because the life-span of $P$. esculentus is only about 28 mo (O'Conner 1979), and the different life-history stages inhabit quite diverse habitats, knowledge of the population dynamics and the responses of the prawns to environmental factors is important in understanding the production of the species.

The population of Penaeus esculentus in Moreton Bay, Queensland, Australia is near the southern limit of the species distribution (Grey et al. 1983). Although other species of prawns such as P. plebejus (Hess) and Metapenaeus bennettae (Racek \& Dall) are more abundant in Moreton Bay, there is a relatively small but important commercial fishery for $P$. esculentus of about 87 tonnes annually (Williams 1991). 
Recruitment and distribution of Penaeus esculentus postlarvae and juveniles in Moreton Bay have been described by Young \& Carpenter (1977) and Young (1978). Growth rates of adults have been estimated from tagging for populations in northern Australia (Kirkwood \& Somers 1984, Derbyshire et al. 1990) and Western Australia (White 1975); however, there is no information on the growth and mortality of juveniles.

In this study I describe settlement and emigration, and estimate growth and mortality of Penaeus esculentus juveniles in the seagrass at Toondah Harbour, Moreton Bay. Because the growth of $P$. esculentus juveniles in aquaria was found to be strongly influenced by water temperature (O'Brien 1992) and Moreton Bay has a marked seasonal water temperature range (Young \& Carpenter 1977), the relationship between water temperature and growth was examined closely. As the fishing grounds are close to the nursery areas, the catches of adult $P$. esculentus probably reflect the success of juveniles in their nursery area. The production of juvenile $P$. esculentus is also discussed with respect to its contribution to the local fishery.

\section{MATERIALS AND METHODS}

Study area. The sampling site was an intertidal seagrass bed (Zostera capricorni Aschers) in Toondah Harbour, Moreton Bay, southeast Queensland: $27^{\circ} 31^{\prime}$ $\mathrm{S}, 153^{\circ} 17^{\prime} \mathrm{E}$ (Fig. 1). This is a typical habitat for juvenile Penaeus esculentus (Staples et al. 1985, Loneragan et al. 1994), albeit near the southern limit of their distribution. The leaf surface area of $Z$. capricorni in Toondah Harbour ranges from about 3 to $10 \mathrm{~m}^{2}$ per $\mathrm{m}^{2}$ of seabed and the mean height of shoots ranges from about 160 to $360 \mathrm{~mm}$ between winter and summer, respectively (O'Brien 1992). Tides are semi-diurnal (i.e. both low and high tides occur twice in $24 \mathrm{~h}$ ) and the seagrass is usually exposed for several hours at low tide. Water depths at high tide ranged from about 1.4 to $2.5 \mathrm{~m}$. A permanent $600 \times 100 \mathrm{~m}$ sampling site was marked by buoys.

Sampling. Prawns were sampled between September 1988 and September 1990 with two $1 \times 0.5 \mathrm{~m}$ beam trawls: one fitted with a $2 \mathrm{~mm}$ mesh net and the other with a $12 \mathrm{~mm}$ mesh net. Several trawls were also made in the sampling area during October and December 1988 with a $2.5 \times 0.5 \mathrm{~m}$ beam trawl fitted with an $18 \mathrm{~mm}$ mesh net. Catches of larger prawns with this net were similar to those from both the 2 and $12 \mathrm{~mm}$ mesh nets.

Prawn sampling was carried out within $4 \mathrm{~d}$ of both the new and full moon at approximately 2 wk intervals. The $600 \times 100 \mathrm{~m}$ sampling site was divided into three $200 \times 100 \mathrm{~m}$ areas. One $200 \mathrm{~m}$ trawl was made with

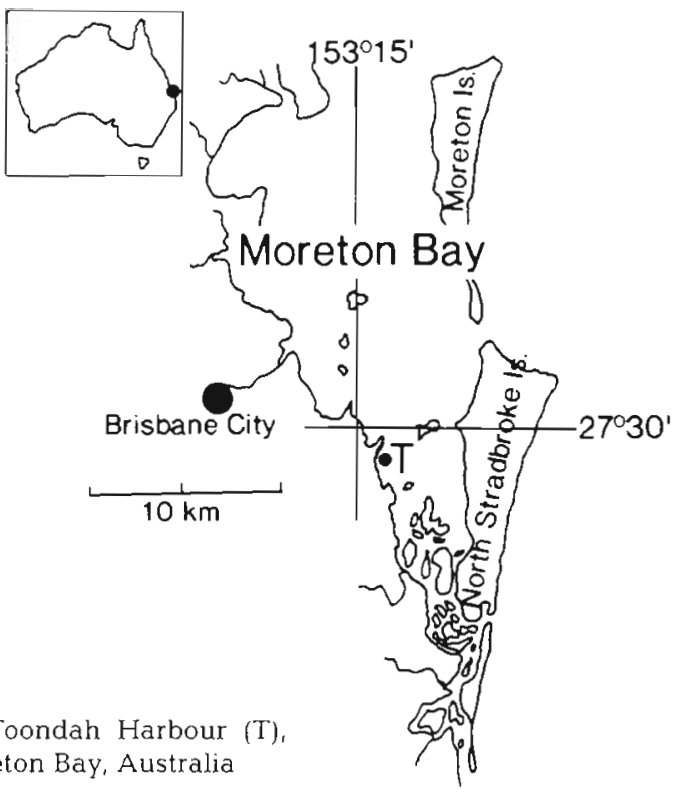

Fig. 1. Toondah Harbour (T) Moreton Bay, Australia

each of the 2 and $12 \mathrm{~mm}$ mesh nets in each area; the starting location for each trawl along the $100 \mathrm{~m}$ line was chosen at random. Trawling was started just after dusk, on a rising tide and in at least $1 \mathrm{~m}$ of water. Trawl direction was always westward. The nets were towed $30 \mathrm{~m}$ behind a $4 \mathrm{~m}$ dinghy over the $200 \mathrm{~m}$ for 6 to $8 \mathrm{~min}$. The catch from each trawl was emptied into a plastic bag, labelled and later frozen. Both water temperature and salinity were measured within $30 \mathrm{~cm}$ of the seabed on each sampling occasion. Daily rainfall was recorded onshore less than $1 \mathrm{~km}$ from the sampling area.

In the laboratory, Penaeus esculentus were identified following the keys of Grey et al. (1983) and Young (1977). Carapace length (CL) was measured (to $0.1 \mathrm{~mm}$ ) with either vernier calipers $(\geq 10 \mathrm{~mm})$ or a dissecting microscope with a graduated eyepiece $(<10 \mathrm{~mm})$. Sex was recorded for prawns $\geq 10 \mathrm{~mm} \mathrm{CL}$. If a carapace could not be measured, the length of the outer uropod (OU) or the telson (TE) was measured instead. These measurements were later converted to $\mathrm{CL}$ using the following $\mathrm{OU}: \mathrm{CL}$ and TE:CL relationships (O'Brien 1992):

$$
\begin{array}{ll}
C L=1.230 U+0.45, & N=182, r^{2}=0.98 \\
C L=1.56 T E+0.51, & N=182, r^{2}=0.98 .
\end{array}
$$

A total length (TL) to CL relationship was determined to enable the comparison of growth rates with other studies which measured TL instead of $\mathrm{CL}$ (O'Brien 1992):

$$
\mathrm{TL}=4.73 \mathrm{CL}+1.75, \quad \mathrm{~N}=119, \mathrm{r}^{2}=0.99 .
$$

Carapace length-irequency analysis. Both the 2 and $12 \mathrm{~mm}$ mesh nets had similar efficiencies for catching prawns $\geq 8 \mathrm{~mm} \mathrm{CL}$ (chi-square, $\mathrm{p}>0.05$ ) but the $2 \mathrm{~mm}$ 


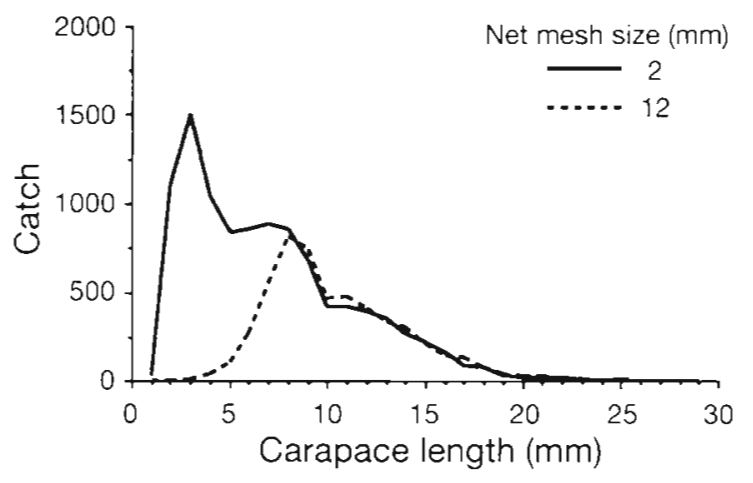

Fig. 2. Penaeus esculentus. Carapace length-frequency distribution of juveniles caught in Toondah Harbour over 2 yr using

2 and $12 \mathrm{~mm}$ mesh nets fitted to $1 \times 0.5 \mathrm{~m}$ beam trawls

mesh net caught a greater numbers of prawns $<8 \mathrm{~mm}$ $\mathrm{CL}$ (Fig. 2). The $12 \mathrm{~mm}$ mesh net was useful in obtaining more of the less numerous larger juveniles in samples that required less sorting time. The final lengthfrequency data set comprising the size and numbers of Penaeus esculentus juveniles was constructed using as much data from both the 2 and $12 \mathrm{~mm}$ mesh nets as possible. All prawns $\geq 8 \mathrm{~mm}$ CL from both nets and only prawns $<8 \mathrm{~mm}$ CL from the $2 \mathrm{~mm}$ mesh net were included. Using data from both nets for prawns $\geq 8 \mathrm{~mm}$ $\mathrm{CL}$ effectively doubled the numbers relative to the catch of prawns $<8 \mathrm{~mm} \mathrm{CL}$. To adjust for this doubling of effort on larger prawns, the number of prawns $<8 \mathrm{~mm} \mathrm{CL}$ caught with the $2 \mathrm{~mm}$ mesh nets was doubled.

Prawns were grouped into $1 \mathrm{~mm}$ CL size classes ( 0.6 to $1.5 \mathrm{~mm}=1 \mathrm{~mm}, 1.6$ to $2.5 \mathrm{~mm}=2 \mathrm{~mm}$, etc.). Lengthfrequency histograms were drawn for each sampling date. Separate modes in each histogram are assumed to represent a distinct cohort of prawns with a mean size and a normal distribution. Because the population was sampled regularly, the progress of related cohorts in successive samples could be followed and growth and mortality can be estimated. For each histogram, normal distribution curves were fitted to each of the component size class means using MIX (Macdonald \& Pitcher 1979). This program also estimated the respective standard deviations and proportions for each component curve in the length-frequency distribution. A theoretical lengthfrequency curve, representing the sum of the component normal distribution curves of each lengthfrequency distribution, was compared to the actual sample distribution (the histogram) using maximum likelihood statistics. The starting values of means and their respective standard deviations and proportions required by MIX were estimated by the methods of Bhattacharya (1967) using ELEFAN (Gayanilo et al. 1989). The length-frequency distributions for Weeks 49 , 51 and 101 were not analysed using MIX because of the low numbers of prawns $(52,26$, and 45 , respectively).
Estimating prawn growth and mortality. The growth rate of each cohort ( $\mathrm{mm} \mathrm{CL} \mathrm{wk}{ }^{-1}$ ) was estimated by linear regression of related size-class means over time. An exponential function was used to describe the relationship between the growth rate of each cohort and the mean water temperature experienced by the cohort over the time that growth was estimated. Water temperatures were recorded by a Yeo-Kal submersible datalogger (model 606) every 30 min for 2 wk on 3 occasions between December 1989 and August 1990. The data showed that the water temperatures recorded during sampling every fortnight were usually about the middle of the $24 \mathrm{~h}$ range. Thus the water temperatures recorded on sampling nights were assumed to be representative of actual mean water temperatures experienced by each cohort of prawns.

The number of prawns in each cohort within each length-frequency distribution $(N)$ was calculated as the cohort proportion (estimated using MIX) multiplied by the total number of prawns caught on the respective sampling date. Weekly instantaneous natural mortality rates $(M)$ for each cohort were estimated for a maximum of $10 \mathrm{wk}$ after settlement as the slope of the regression line of $\log _{e} N$ against time (Ricker 1975) using:

$$
\log _{\mathrm{e}} N=-M T+a
$$

where $N=$ number of prawns from a fully recruited cohort at time $T ; M=$ natural mortality; and $a=$ the intercept. In each case, the regression calculations were made from the time the cohort was fully recruited and ceased prior to emigration. The mean size of prawns in a new, fully recruited cohort was at least $3 \mathrm{~mm} \mathrm{CL}$, i.e. the smallest size of prawn reliably caught by the nets (Fig. 2). The percentage natural mortality (or conditional natural mortality rate; Ricker 1975) per week was also calculated:

$$
\left(1-\mathrm{e}^{-M}\right) \times 100 .
$$

No mortality estimates were made for Cohorts 3 or 4 because the densities of prawns in successive samples initially decreased then increased again to their original recruitment levels.

Estimating prawn size at emigration. Examination of plots of the percent fortnightly decrease in relative abundance (DRA) of each cohort against prawn size indicated that for most cohorts, there was an abrupt decrease in relative abundance. This was assumed to indicate en masse emigration of a cohort from the seagrass bed. The mean prawn size at the start of emigration was determined for each cohort by

$$
\mathrm{DRA}=\left(N_{t} / N_{t+1}\right) \times 100
$$

where $N$ = relative abundance of prawns in a cohort at a week $(t)$. For example, emigration $(E)$ is taken to have occurred at the prawn size prior to the abrupt change in 


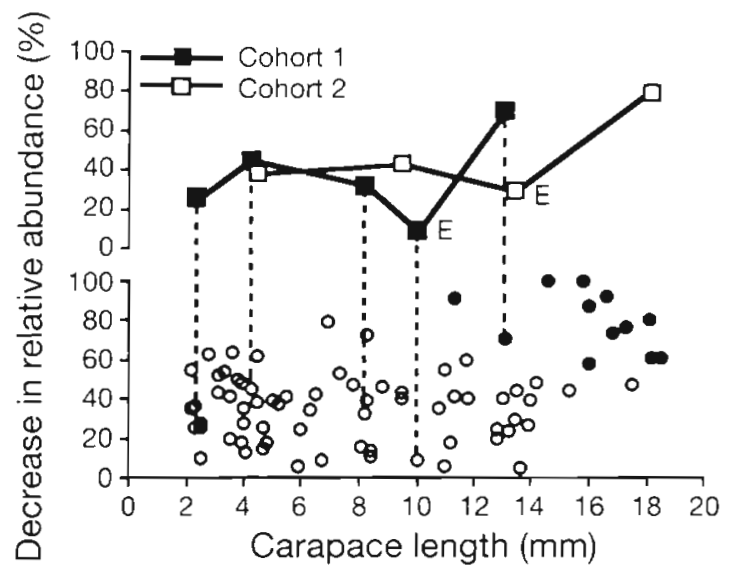

Fig. 3. Penaeus esculentus. An example of the method used to determine the size at emigration (E) for each cohort of prawns. Lines indicate relative abundance history of Cohorts 1 and 2. Size at emigration is taken as the size prior to the abrupt decrease in relative abundance (DRA). In the lower part of the graph DRA data for all cohorts are given. (•) Abrupt DRAs; (o) 'normal' DRAs

DRA which was $10 \mathrm{~mm} \mathrm{CL}$ for Cohort 1 and $13.4 \mathrm{~mm} \mathrm{CL}$ for Cohort 2 (Fig. 3). Data for the 12 cohorts for which emigration was apparent are shown in the lower part of Fig. 3: the open circles indicate 'normal' DRAs and the closed circles indicate abrupt DRAs.

\section{RESULTS}

\section{Environment}

Total rainfall at Toondah Harbour during each of the 2 years of the study was similar: $1412.5 \mathrm{~mm}$ between September 1988 and September 1989 and $1470.5 \mathrm{~mm}$ between September 1989 and September 1990 (Fig. 4a). Salinity ranged from 22.3\% (April 1989) to $36.2 \%$ (January 1990) and was most variable between December and June following heavy rain (Fig. $4 \mathrm{~b}$ ). Water temperatures were lowest in winter: $12.7^{\circ} \mathrm{C}$ in July 1989 and $13.5^{\circ} \mathrm{C}$ in July 1990, and increased steadily to peak in summer: $30.6^{\circ} \mathrm{C}$ in January 1989 and $29.6^{\circ} \mathrm{C}$ in February 1990 (Fig. 4C).

\section{Prawn seasonality}

A total of 15492 Penaeus esculentus juveniles ranging from 1.1 to $29.1 \mathrm{~mm}$ CL were caught in Toondah Harbour between September 1988 and September 1990. About half of the prawns were caught on the new (7772) and full (7720) moons, respectively. The ratio of male to female juveniles $\geq 10 \mathrm{~mm}$ CL (estimated for each $2 \mathrm{wk}$ period) did not differ from 1:1 (chi-square, $\mathrm{p}>0.05$ ).
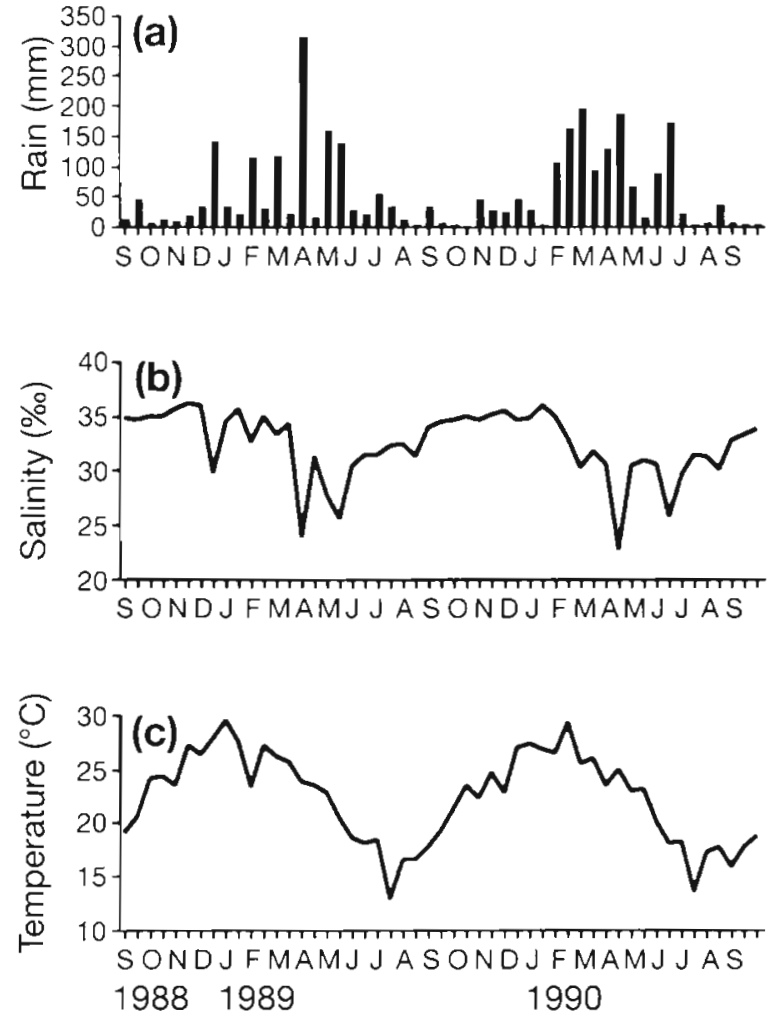

Fig. 4. Toondah Harbour. (a) Rainfall, (b) mean salinity and (c) mean water temperature measured fortnightly between September 1988 and September 1990

Small Penaeus esculentus juveniles $(\leq 3.5 \mathrm{~mm} \mathrm{CL}$ ) were present on the seagrass from September to July in both years (Fig. 5a). The first peak in settlement occurred from September to November. A second, slightly more protracted peak of settlement occurred

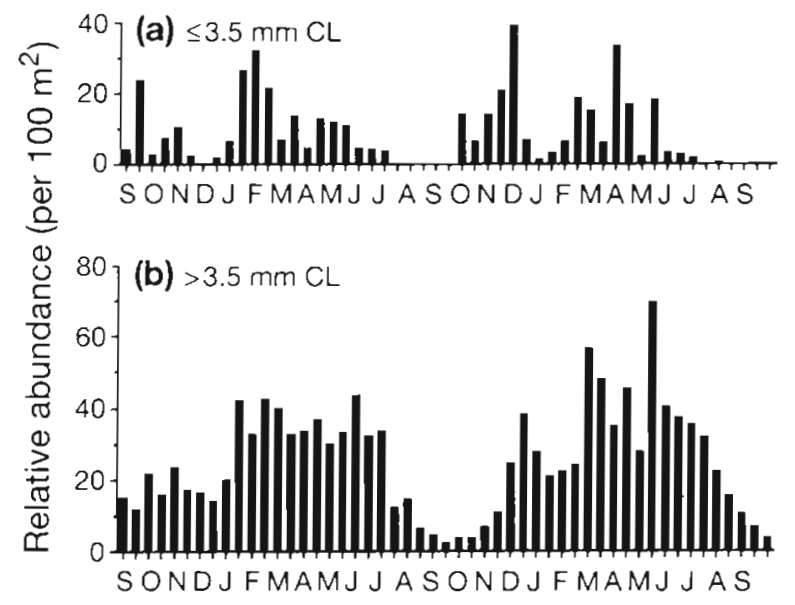

Fig. 5. Penaeus esculentus. Relative abundance of juveniles per $100 \mathrm{~m}^{2}$ of seabed sampled in Toondah. Harbour between September 1988 and September 1990. (a) $\leq 3.5 \mathrm{~mm}$ carapace length, (b) $>3.5 \mathrm{~mm}$ carapace length 
from late January to April. Relatively high numbers of small prawns continued to settle until May; few prawns settled between June and early September. There was a marked seasonality in the relative abundance of $P$. esculentus juveniles ( $>3.5 \mathrm{~mm} \mathrm{CL}$ ). Although juveniles were present all year round, the highest numbers were found around January to June (Fig. 5b).

The mean sizes at which Penaeus esculentus started to emigrate from the seagrass bed ranged from 11.3 to $18.5 \mathrm{~mm}$ CL (Table 1); the overall mean ( $\pm \mathrm{SE}$ ) was about $16 \pm 0.6 \mathrm{~mm} \mathrm{CL}$.

\section{Growth rates}

Over the $2 \mathrm{yr}, 19$ immigrant cohorts of Penaeus esculentus juveniles were identified and followed through time: 10 in 1988/89 and 9 in 1989/90 (Fig. 6). Linear regressions of growth against time provided good fits to the growth data where rates were $\geq 0.2 \mathrm{~mm} \mathrm{wk}^{-1}$ (in these cases, $\mathrm{r}^{2}$ values were $\geq 0.78$ ). The growth rates of $P$. esculentus juveniles ranged from 0.03 to $2.1 \mathrm{~mm} \mathrm{CL} \mathrm{wk^{-1 }}$ (Table 1 ). In some cases, 2 growth rates were estimated for a cohort because of a marked change in the shape of the curve, e.g. Cohort 1: 25 November 1988 (Fig. 6). Such changes in growth usually coincided with a seasonal change in mean water temperature. Cohorts which arrived between November and January grew quickly (1.1 to $2.1 \mathrm{~mm} \mathrm{CL} \mathrm{wk}^{-1}$ ) and could only be followed for between 5 and 8 fortnights (i.e. 10 to $16 \mathrm{wk}$ ). Cohorts which arrived around March grew more slowly $(\leq 1.0$ $\mathrm{mm} \mathrm{CL} \mathrm{wk} \mathrm{k}^{-1}$ ) and were followed for 11 to 14 fortnights (i.e. 22 to 28 wk) (Table 1, Fig. 6).

Growth rates (GR; mm CL wk ${ }^{-1}$ ) increased as mean water temperatures $\left(T ;{ }^{\circ} \mathrm{C}\right)$ increased and the relationship between the two could be described by:

$$
G R=0.00044 e^{0.31 T} \quad N=28, r^{2}=0.89 \text { (Fig. 7) }
$$

Summer growth rates during the first year were faster than those in the second year, e.g. the fastest

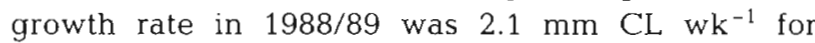
Cohorts $2 \mathrm{~b}$ and 4 , compared with $1.3 \mathrm{~mm} \mathrm{CL} \mathrm{wk}^{-1}$ (Cohort 12) in $1989 / 90$. The fast growth rates in

Table 1. Penaeus esculentus. Estimates of population parameters for juveniles collected fortnightly in Toondah Harbour between September 1988 and September 1990. Mortality was estimated over a maximum of 10 wk after settlement. CL: carapace length $M$ : instantaneous mortality rate; na: no emigration apparent

\begin{tabular}{|c|c|c|c|c|c|c|}
\hline \multirow[t]{2}{*}{ Cohort } & \multirow{2}{*}{$\begin{array}{c}\text { Date of } \\
\text { settlement }\end{array}$} & \multirow{2}{*}{$\begin{array}{l}\text { Size at } \\
\text { emigration } \\
(\mathrm{mm} \mathrm{CL})\end{array}$} & \multirow{2}{*}{$\begin{array}{l}\text { Growth rate } \\
(\mathrm{mm} \mathrm{CL} \mathrm{wk-1)})\end{array}$} & \multirow{2}{*}{$\begin{array}{l}\text { Period over which } \\
\text { growth was } \\
\text { estimated }\end{array}$} & \multicolumn{2}{|c|}{ Mortality $\left(w^{-1}\right)$} \\
\hline & & & & & $M$ & $\%$ \\
\hline \multirow[t]{2}{*}{1} & $23 \operatorname{Sep} 88$ & 13.1 & 0.9 & 23 Sep $88-25$ Nov 88 & 0.12 & 11.3 \\
\hline & & & 2.0 & 25 Nov $88-5$ Jan 89 & & \\
\hline \multirow[t]{2}{*}{2} & 24 Oct 88 & 18.1 & 0.9 & 24 Oct $88-25$ Nov 88 & 0.13 & 12.2 \\
\hline & & & 2.1 & 25 Nov $88-22 \operatorname{Jan} 89$ & & \\
\hline 3 & 10 Nov 88 & 16.6 & 1.6 & 10 Nov $88-22 \operatorname{Jan} 89$ & \multicolumn{2}{|c|}{ No estimate made } \\
\hline 4 & 21 Dec 88 & 17.3 & 2.1 & 21 Dec $88-20$ Feb 89 & \multicolumn{2}{|c|}{ No estimate made } \\
\hline 5 & $5 \mathrm{Jan} 89$ & 16.0 & 1.2 & 5 Jan $89-7$ Apr 89 & 0.22 & 19.7 \\
\hline \multirow[t]{2}{*}{6} & $22 \operatorname{Jan} 89$ & 18.2 & 1.1 & 22 Jan 89 - 4 May 89 & 0.26 & 22.9 \\
\hline & & & 0.5 & 4 May 89 - 18 Jun 89 & & \\
\hline \multirow[t]{2}{*}{7} & 7 Feb 89 & 11.3 & 1.1 & 7 Feb $89-4$ May 89 & 0.10 & 9.5 \\
\hline & & & 0.1 & 4 May 89 - 2 Jun 89 & & \\
\hline \multirow[t]{2}{*}{8} & 7 Mar 89 & na & 1.1 & 7 Mar 89 - 4 May 89 & 0.13 & 12.2 \\
\hline & & & 0.06 & 4 May $89-16$ Aug 89 & & \\
\hline \multirow[t]{2}{*}{9} & 21 Mar 89 & na & 0.7 & 21 Mar 89 - 22 May 89 & 0.08 & 7.7 \\
\hline & & & 0.03 & 22 May $89-16$ Aug 89 & & \\
\hline \multirow[t]{2}{*}{10} & 20 Apr 89 & na & 0.3 & 20 Apr $89-2$ Jun 89 & 0.13 & 12.2 \\
\hline & & & 0.1 & 2 Jun $89-16$ Aug 89 & & \\
\hline 11 & 30 Sep 89 & na & 0.8 & 30 Sep $89-13$ Nov 89 & 0.24 & 21.3 \\
\hline 12 & 30 Oct 89 & 16.0 & 1.3 & 30 Oct $89-26$ Jan 90 & 0.22 & 19.7 \\
\hline 13 & 13 Nov 89 & 18.5 & 1.2 & 13 Nov $89-12$ Mar 90 & 0.29 & 25.2 \\
\hline 14 & 29 Nov 89 & 16.8 & 1.1 & 29 Nov $89-12$ Mar 90 & 0.18 & 16.5 \\
\hline 15 & 9 Jan 90 & 14.6 & 1.2 & $9 \operatorname{Jan} 90-28 \operatorname{Mar} 90$ & 0.11 & 10.4 \\
\hline 16 & 26 Jan 90 & 15.8 & 0.9 & $26 \operatorname{Jan} 90-11$ May 90 & 0.22 & 19.7 \\
\hline \multirow[t]{2}{*}{17} & 26 Feb 90 & na & 0.7 & 26 Feb $90-9$ Jun 90 & 0.06 & 5.8 \\
\hline & & & 0.1 & 9 Jun $90-5 \operatorname{Sep} 90$ & & \\
\hline \multirow[t]{2}{*}{18} & 28 Мar 90 & na & 0.5 & 28 Mar $90-9$ Jun 90 & 0.06 & 5.8 \\
\hline & & & 0.1 & 9 Jun $90-5 \operatorname{Sep} 90$ & & \\
\hline 19 & 11 May 90 & nà & 0.2 & 11 May $90-6$ Jul 90 & 0.13 & 12.2 \\
\hline
\end{tabular}



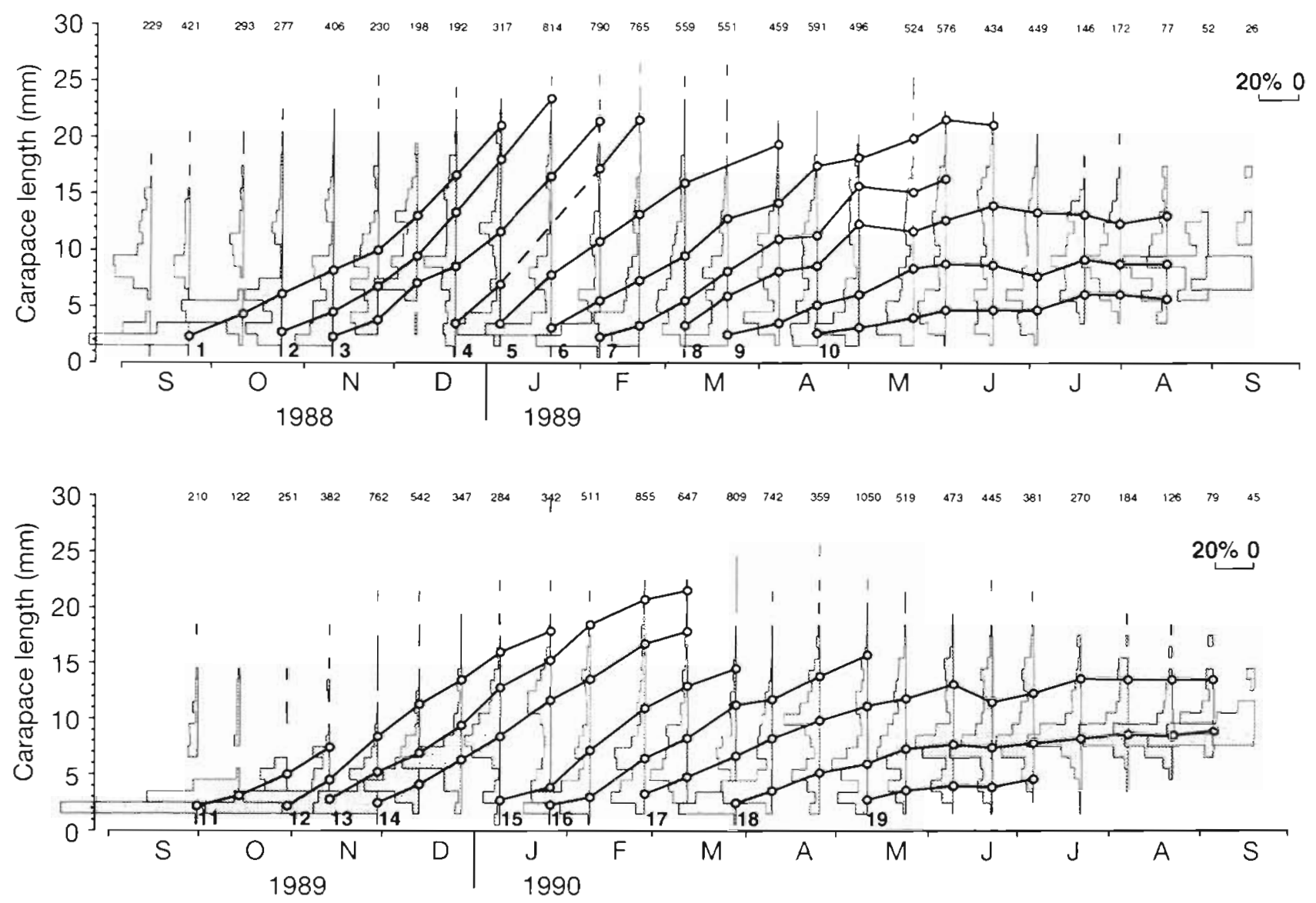

Fig. 6. Penaeus esculentus. Length-frequency histograms and growth curves for juveniles in Toondah Harbour between September 1988 and September 1990. Each cohort is numbered. (ㅇ) Mean size of each cohort through time. The number of prawns in each length-frequency distribution is shown along the top of each figure

1988/89 coincided with warmer average water temperatures. Cohorts which remained on the seagrass during winter had very slow growth rates $(\leq 0.2 \mathrm{~mm} \mathrm{CL}$ wk ${ }^{-1}$ ) e.g. Cohorts $8,9,10,17,18$ and 19 (Fig. 6).

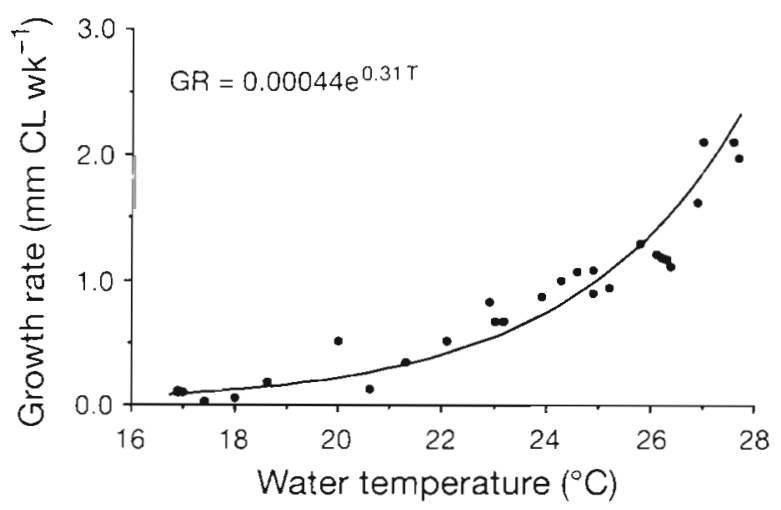

Fig. 7. Penaeus esculentus. Relationship between growth rates of each cohort of juveniles and mean water temperatures experienced by each cohort. GR: growth rate $\left(\mathrm{mm} \mathrm{CL} \mathrm{wk}^{-1}\right)$; $T$. water temperature $\left({ }^{\circ} \mathrm{C}\right)$; $\mathrm{CL}$ : carapace length. $\mathrm{N}=28, \mathrm{r}^{2}=0.89$

\section{Mortality}

Instantaneous rates of natural mortality of Penaeus esculentus juveniles in Toondah Harbour ranged from $M=0.06$ to $0.29 \mathrm{wk}^{-1}$ or 5.8 to $25.2 \% \mathrm{wk}^{-1}$ (Table 1 ). Mortality rates tended to be highest in cohorts which settled in summer (December to February) and lowest in cohorts settling after February (Fig. 8), but there was no correlation $(p>0.05)$ between mortality rates and mean water temperature. Mean values of $M \pm S E$ for each year were $0.15 \pm 0.02$ and $0.17 \pm 0.01$ or $13.6 \pm 2.0$ and $15.2 \pm 2.3 \% \mathrm{wk}^{-1}$ for the first (Cohorts 1 to 10 ) and second year (Cohorts 11 to 19), respectively.

\section{DISCUSSION}

\section{Settlement}

Peaks in the settlement of Penaeus esculentus juveniles onto the Toondah Harbour seagrass were between September and November and late January to 


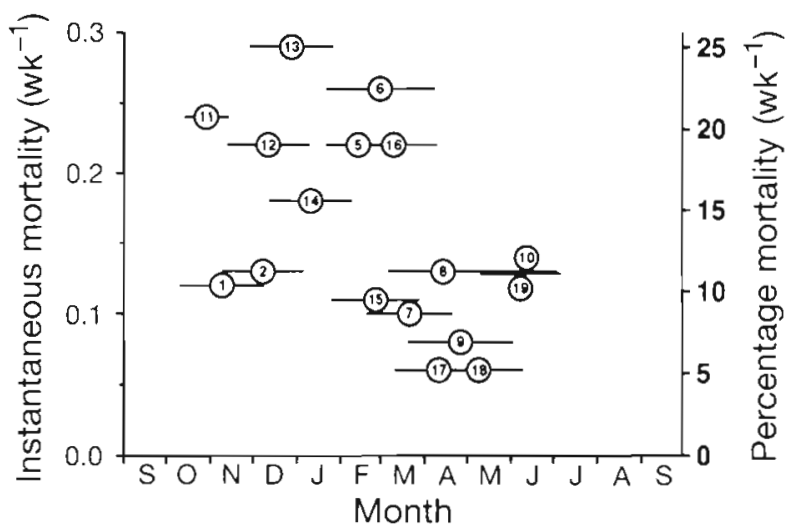

Fig. 8. Penaeus esculentus. Natural rates of mortality of cohorts (numbered) of juveniles in Toondah Harbour. Mortality was estimated over a maximum of $10 \mathrm{wk}$ after settlement. Cohorts 1 to 10 were sampled between September 1988 and September 1989. Cohorts 11 to 19 were sampled between September 1989 and September 1990. The span of each line indicates the period over which the mortality rate was estimated. Mortality rates were not estimated for Cohorts 3, 4 and 11 (refer to text)

April. The timing of settlement of $P$. esculentus juveniles in this study was consistent with that described by Young \& Carpenter (1977) and Young (1978) for the greater Moreton Bay area and most other P. esculentus populations within the species range (Heasman 1983, Turnbull \& Mellors 1990, N. R. Loneragan, CSIRO Division of Fisheries, unpubl.).

Assuming a larval life of about 4 wk (Dall et al. 1990), the timing of the first settlement (September) indicates that the first concerted spawning activities were probably in August. Interestingly, during an independent but concurrent 2 yr survey of the reproductive dynamics of Penaeus esculentus in Moreton Bay, there was little evidence of reproductive activity in August - the

Table 2. Penaeus spp. Field estimates of instantaneous growth rates of juvenile prawns. The studies listed were conducted on similar sized prawns using similar sampling methods. CL: carapace length; TL: total length

\begin{tabular}{|c|c|c|c|}
\hline \multicolumn{4}{|c|}{ Instantaneous growth (mm wk $\mathrm{wk}^{-1}$ ) } \\
\hline Species & $\mathrm{CL}$ & TL & Source \\
\hline P. aztecus & & $3.6-6.1^{\mathrm{a}}$ & Knudsen et al. (1977) \\
\hline P. aztecus & & $0.9-13.0$ & Laney (1981) \\
\hline P. aztecus & & $6.1-7.6^{\mathrm{a}, \mathrm{b}}$ & Minello et al. (1989) \\
\hline P. duorarum & & $4.1-7.9^{\mathrm{a}}$ & Alvarez et al. (1987) \\
\hline P. esculentus & $0.03-2.1$ & $0.1-10$ & This study \\
\hline P. esculentus & $0.8-1.6$ & & Loneragan et al. (1994) \\
\hline P. merguiensis & $0.6-1.7$ & & Haywood \& Staples (1993) \\
\hline$P$. setiferus & & $0.4-13.4$ & Laney (1981) \\
\hline P. vannamei & & $5.6-9.8^{a}$ & Edwards (1977) \\
\hline
\end{tabular}

major spawning activities started between October and November (A. J. Courtney, Queensland Department of Primary Industries Fisheries Branch, unpubl.). Thus, it is possible that the first $P$. esculentus postlarvae may have come from a relatively low reproductive effort in August or from deep water spawnings outside Moreton Bay.

\section{Growth}

Although it is difficult to isolate the effects of environmental factors in field studies, water temperature has been reported to be a major factor affecting the growth of Penaeus juveniles in the wild (e.g. Gaidry \& White 1973, Haywood \& Staples 1993). However, few workers have provided detailed examinations of growth rate:water temperature relationships other than broad descriptions of seasonal changes in growth.

Water temperature appeared to have a marked effect on the growth of Penaeus esculentus in Toondah Harbour with growth rates reflecting the seasonality of the water temperatures. Growth rates exceeded $1 \mathrm{~mm}$ CL $w^{-1}$ when average water temperatures were above $25^{\circ} \mathrm{C}$, usually between December and March. The fastest growth rates of about $2 \mathrm{~mm} \mathrm{CL} \mathrm{wk}^{-1}$ were recorded when average water temperatures were above $27^{\circ} \mathrm{C}$; these fast growth rates occurred for about 1 mo of the year, around January to February. Cohorts of prawns which settled in Toondah Harbour after midFebruary in both years were strongly affected by the autumn decrease in water temperature and their growth decreased to $<25 \%$ of summer rates.

The estimates of the growth rates of Penaeus esculentus juveniles in this study were similar to those reported for juveniles of other Penaeus species (Table 2). The summer (fastest) growth rates of Penaeus juveniles in the wild are broadly similar (allowing for differences in the thermal histories of the prawns) and can exceed $2 \mathrm{~mm} \mathrm{CL} \mathrm{wk}{ }^{-1}$. Those studies which included estimates of growth during winter characteristically showed a period where growth was very slow $\left(<0.5 \mathrm{~mm} \mathrm{CL} \mathrm{wk}^{-1}\right)$.

Laboratory studies indicate that water temperature is probably the major factor affecting the growth of prawns (ZeinEldin \& Griffith 1969, Staples \& Heales 1991, O'Brien 1992). In aquaria, growth rates of individual prawns can be described by the ratio of the moult increment to the duration of the intermoult period of successive ecdyses (Botsford 1985). Laboratory studies on juvenile Penaeus esculentus revealed that the moult increment of juveniles reared in water temperatures 
ranging from 20 to $35^{\circ} \mathrm{C}$ was relatively constant, but the duration of the intermoult period increased rapidly as temperature decreased; e.g. at a salinity of $30 \%$, the growth rates of $12 \mathrm{~mm} \mathrm{CL} P$. esculentus reared at $24^{\circ} \mathrm{C}$ was almost half that of prawns reared at $28^{\circ} \mathrm{C}$ because the intermoult period increased from 5 to $9 \mathrm{~d}\left(\mathrm{O}^{\prime} \mathrm{Brien}\right.$ 1992). The results of this laboratory study help explain the response of the wild prawns in Toondah Harbour to seasonal changes in water temperatures.

Laboratory studies have also shown that the salinities recorded during this study (range: 22.3 to $36.2 \%$ ) are not likely to have influenced the growth of Penaeus esculentus juveniles (O'Brien 1992).

Growth of Pendeus postlarvae in the wild can be retarded by high settlement densities (Alvarez et al. 1987, Haywood \& Staples 1993). However, it is a characteristic of Penaeus that the abundance of small juveniles decreases rapidly over several weeks. Densitjes of larger juveniles are generally less than 6 prawns $\mathrm{m}^{-2}$ (e.g. Zimmerman et al. 1984, Minello et al. 1989, Haywood \& Staples 1993). Assuming a net efficiency of between 35 to $50 \%$ (N. R. Loneragan, CSIRO Division of Fisheries, unpubl.), the maximum density of $P$. esculentus juveniles (all sizes) in Toondah Harbour in this study was less than 3 prawns $\mathrm{m}^{-2}$ of seagrass bed. Laboratory studies indicate that such a density would have little effect on the growth of $P$. esculentus (O'Brien 1992).

\section{Emigration}

The residence time of Penaeus esculentus juveniles in Toondah Harbour increased markedly as summer progressed. For example, most juveniles in Cohort 4 , which settled in December 1988, had a residence time of about $10 \mathrm{wk}$. Juveniles which settled after midFebruary and experienced mean water temperatures below $23^{\circ} \mathrm{C}$, did not appear to emigrate en masse and a number of these prawns overwintered, e.g. some juveniles in Cohort 9, which settled in late March 1989, appeared to stay for up to $34 \mathrm{wk}$.

It is possible that there is some continuous, low level of emigration by prawns from the seagrass bed into deeper water. However, for most cohorts, an abrupt decrease in numbers was detected and this was assumed to indicate emigration en masse. Most Penaeus esculentus juveniles start to emigrate from the Toondah Harbour seagrass bed at a size of about $16 \mathrm{~mm}$ CL. Emigration was apparently not stimulated by water temperature or salinity; thus it is likely to be a response to physiological cues associated with increasing size (Dall et al. 1990). By contrast, $P$. esculentus in tropical areas migrate from nursery areas at about $10 \mathrm{~mm} \mathrm{CL}$ (Turnbull \& Mellors 1990, Loneragan et al.
1994); although the reasons for this difference are not clear, high water temperatures in tropical shallows may be a factor. For other Penaeus species, changes in the environment such as monsoonal, rain-induced salinity drops can stimulate juveniles to emigrate at much smaller sizes (Staples \& Vance 1986). Haywood \& Staples (1993) found that newly settled Penaeus merguiensis (de Man) may spend as little as 2 wh in their nursery if rainfall is high. In subtropical Gulf of Mexico, sharp drops in shallow water temperature may cause the emigration of juvenile Penaeus setiferus (Linnaeus) (Pullen \& Trent 1969).

\section{Mortality}

Juvenile prawn stocks are causing concern for fisheries managers because they are being increasingly harvested for food and bait (UNESCO 1988). Further, prawn nursery areas are being considered for stock enhancement programs where laboratory-reared juveniles are released into nursery areas to boost natural stocks (e.g. Liu et al. 1991). To enable accurate assessments of the effects of fishing and stock enhancement on prawn stocks, managers require accurate estimates of natural mortality from unfished populations; currently, such information is rare.

The rates of natural mortality of Penaeus esculentus in Toondah Harbour ranged from 5.8 to $25.2 \% \mathrm{wk}^{-1}$ with mean mortality rates (September to August) of 13.6 and $15.2 \% \mathrm{wk}^{-1}$ for $1988 / 89$ and $1989 / 90$, respectively. In a study of an unfished population of juvenile Penaeus aztecus (Ives) in a Galveston Bay saltmarsh, Gulf of Mexico, analysed using similar methods, the upper level of mortality was $33.6 \% \mathrm{wk}^{-1}$ (Minello et al. 1989) - similar to that estimated in the current study. In contrast, mortality rates of juvenile $P$. merguiensis in the Embley River, northeast Gulf of Carpentaria, Australia, ranged up to $60.9 \% \mathrm{wk}^{-1}$ (Haywood \& Staples 1993 ) and the yearly mean mortality rates over the 3 yr study $\left(26,38.7\right.$ and $\left.36.9 \% \mathrm{wk}^{-1}\right)$ were much higher than those of $P$. esculentus in Toondah Harbour.

Studies have shown that fish are probably the major cause of mortality to juvenile prawns (Minello et al. 1989) but that the presence of vegetation often reduces the success of fish predators (Minello \& Zimmerman 1983, Minello et al. 1989, Laprise \& Blaber 1992). This is consistent with the mortality rates of Penaeus esculentus and $P$. aztecus because both these species live in vegetated habitats and have lower rates of natural mortality. $P$. merguiensis, however, live on the relatively bare mud banks of mangroves and have comparatively higher rates of mortality. Other factors such as adverse environmental conditions and habitat characteristics including hydroperiod, turbidity and the 
nature of the sediment can also affect the mortality of juvenile prawns (Minello \& Zimmerman 1991).

The water temperatures and salinities in Toondah Harbour over the 2 yr study period were moderate: 12.7 to $30.6^{\circ} \mathrm{C}$ and 22.3 to $36.2 \%$, respectively. Laboratory experiments indicate that most combinations of these temperatures and salinities (except for extreme low temperature and salinity) would be easily tolerated by Penaeus esculentus juveniles (O'Brien 1992). Thus, predation by fishes is probably the major source of mortality of $P$. esculentus juveniles in Toondah Harbour. Interestingly, as the abundance of juvenile fishes in Moreton Bay peaks over summer (Blaber \& Blaber 1980) so too do the mortality rates of $P$. esculentus. However, it is likely that the turbidity (pers. obs.), the large surface area of seagrass available (e.g. ca $10 \mathrm{~m}^{2}$ seagrass per $\mathrm{m}^{2}$ seabed; O'Brien 1992) and relatively low prawn densities contribute to the low levels of predation by fish.

\section{Implications for the fishery}

As the mortality rates of juvenile Penaeus esculentus appear to be independent of water temperature and are relatively low, the production of adult $P$. esculentus in the Moreton Bay fishery will be strongly influenced by the number and size of cohorts of juveniles settling in the nursery areas and their growth. If the numbers or sizes of cohorts settling in the bay area decreases, and/or the timing of settlement is late and the prawns experience only cool water, the commercial catches of adult $P$. esculentus would be severely reduced.

In each year, 3 cohorts of prawns settled after midFebruary. These prawns were affected by the decreasing water temperatures such that their growth slowed markedly and they appeared to overwinter on the seagrass bed. The contribution of these cohorts to the fishery in their first year was probably low. However, it is possible that some of these prawns become the larger sized prawns of the next season's fishery.

The largest catches of adult Penaeus esculentus are usually taken by the fishery in February (Courtney et al. 1991). The 3 or 4 cohorts of juveniles which settle between September and December grow rapidly and probably provide the large (February) catches of adults in the fishery. The reproductive effort which produced the first 3 or 4 cohorts of the season is apparently very small (A. J. Courtney, Queensland Department of Primary Industries Fisheries Branch, unpubl.). This apparent mismatch between the size of the spawning population and the importance of subsequent postlarvae to the juvenile and adult stocks has also been reported for $P$. merguiensis in the Gulf of Carpentaria (Staples 1991).
Acknowledgements. This work formed part of a Ph.D. at the University of New South Wales. Support was received from an Australian Postgraduate Research Award. Thanks to CSIRO Division of Fisheries Marine Laboratory, Cleveland for the use of equipment and facilities. J. Maclntyre (University of NSW), D. Staples (Bureau of Rural Sciences, Canberra), B. Hill, N. Loneragan and 1 . Somers (CSIRO) gave constructive criticism of drafts of this manuscript.

\section{LITERATURE CITED}

Alvarez, F. N., Gracia, A. G., Soto, L. A. (1987). Crecimiento y mortalidad de las fases estuarinas del camaron rosado Penaeus (Farfantepenaeus) duorarum Burkenroad, 1939 en la Laguna de Terminos, Campeche. Anale Instituto Ciencias del Mar y Limnologia, Universidad Nacional Autonoma, Mexico

Bhattacharya, C. G. (1967). A simple method of resolution of a distribution into its Gaussian components. Biometrics 23 : $115-135$

Blaber, S. J. M., Blaber, T. G. (1980). Factors affecting the distribution of juvenile estuarine and inshore fish. J. Fish. Biol. 17: 143-162

Botsford, L. W. (1985). Models of growth. In: Wenner, A. M. (ed.) Crustacean issues No. 3: Factors in adult growth. A. A. Balkema, Rotterdam, p. 171-187

Coles, R. G., Lee Long, W. J., Squire, B. A., Squire, L. C., Bibby, J. M. (1987). Distribution of seagrasses and associated juvenile commercial penaeid prawns in northeastern Queensland waters. Aust. J mar. Freshwat. Res. 38: $103-119$

Courtney, A. J., Masel, J. M., Die, D. J. (1991). An assessment of recently introduced seasonal prawn trawl closures in Moreton Bay, Queensland. Queensland Department of Primary Industries Fisheries Branch information series Q191037

Dall, W., Hill, B. J., Rothlisberg, P. C., Staples, D. J. (1990). The biology of the Penaeidae. In: Blaxter, J. H. S., Southward, A. J. (eds.) Advances in marine biology, Vol. 27. Academic Press, London, p. 1-489

Derbyshire, K. J., Sterling, D. J., Watson, R. A., Lisle, A. (1990). Movement and growth of Penaeus esculentus (Haswell, 1879) estimated from tagging in Torres Strait. In: Mellors, J. E. (ed.) Torres Strait Prawn Project review of research 1986-88. Queensland Department of Primary Industries Fisheries Branch information series Q190018, p. $62-72$

Edwards, R. R. C. (1977). Field experiments on growth and mortality of Penaeus vannamei in a Mexican coastal lagoon complex. Estuar. coast. mar. Sci. 5: 107-121

Gaidry, W. J., White, C. J. (1973). Investigations of commercially important penaeid shrimp in Louisiana estuaries. Louisiana Wildlife and Fisheries Commission Tech. Bull. 8

Gayanilo, F. C. J., Soriano, M., Pauly, D. (1989). A draft guide to the compleat ELEFAN. ICLARM software 2. International Centre for Living Aquatic Resources Management, Manila

Grey, D. L., Dall, W., Baker, A. (1983). A guide to the Australian penaeid prawns. Department of Primary Production, Northern Territory, Australia

Haywood, M. D. E., Staples, D. J. (1993). Growth and mortality of juvenile banana prawns (Penaeus merguiensis de Man). Mar. Biol. 116: 407-416

Heasman, M. (1983). Queensland team studying northern prawns. Aust. Fish. 1: 17-19

Kirkwood, G. P., Somers, I. F. (1984). Growth of two species of 
tiger prawn Penaeus esculentus and P. semisulcatus, in the western Gulf of Carpentaria. Aust. J. mar. Freshwat. Res. 35: $703-712$

Knudsen, E. E., Herke, W. H., Mackler, J. M. (1977). The growth rate of marked juvenile brown shrimp, Penaeus aztecus, in a semi-impounded Louisiana coastal marsh. Gulf and Caribbean Fisheries Institute, 29th Annual Session, November 1976, p. 144-159

Laprise, R., Blaber, S. J. M. (1992). Predation by Moses perch, Lutjanus russelli, and blue-spotted trevally, Caranx bucculentus, on juvenile brown tiger prawn, Penaeus esculentus: effects of habitat structure and time of day. J. Fish Biol. 40:627-635

Laney, R. W. (1981). Population dynamics of penaeid shrimp in two North Carolina tidal creeks. Ph.D. thesis, Graduate Faculty of North Carolina State University

Liu, J. Y., Cui, F. S. Xu, Xiang, J. H. (1991). Recruitment and stock enhancement of the Chinese shrimp. Penaeus orientalis Kishinouye (Decapoda, Crustacea). Mem. Qd Mus. 31: 454

Loneragan, N. R., Kenyon, R. A., Haywood, M. D. E., Staples, D. J. (1994). Population dynamics of juvenile tiger prawns (Penaeus esculentus and Penaeus semisulcatus) in seagrass habitats of the western Gulf of Carpentaria, Australia. Mar. Biol (in press)

Macdonald, P. D. M., Pitcher, T J. (1979). Age-groups from size-frequency data: a versatile and efficient method of analysing distribution mixtures. J. Fish. Res. Bd Can. 36: $987-1001$

Minello, T J., Zimmerman, R. J. (1983). Fish predation on juvenile brown shrimp, Penaeus aztecus Ives: the effect of simulated Spartina structures on predation rates. J. exp. mar. Biol. Ecol. 72: 211-231

Minello, T. J., Zimmerman, R. J. (1991). The role of estuarine habitats in regulating growth and survival of juvenile penaeid shrimp. In: DeLoach, P. F., Dougherty, W. J., Davidson, M. A. (eds.) Frontiers of shrimp research. Elsevier, New York, p. 1-16

Minello, T. J., Zimmerman, R. J., Martinez, E. X. (1989). Mortality of young brown shrimp Penaeus aztecus in estuarine nurseries. Trans. Am. Fish. Soc. 118: 693-708

O'Brien, C. J. (1992). Some aspects of the production ecology of Penaeus esculentus Haswell (Decapoda: Penaeidae) juveniles. Ph.D. thesis, University of New South Wales

O'Conner, C. (1979). Reproductive periodicity of a Penaeus esculentus population near Low Islets, Queensland, Australia. Aquaculture 16: 153-162

Penn, J. W. (1981). A review of mark-recapture and recruitment studies on Australian penaeid shrimp. Kuwait Bull. mar. Sci. 2: 227-247

Pullen, E. J., Trent, W. L. (1969). White shrimp emigration in relation to size, sex, temperature and salinity. FAO Fish.

This article was presented by G. F. Humphrey, Sydney, Australia
Rep. 57: $1001-1014$

Ricker, W. E. (1975). Computation and interpretation of the biological statistics of fish populations. Bull. Fish. Res. Bd Can. 191

Staples, D. J. (1991). Penaeid prawn recruitment: geographic comparison of recruitment patterns within the Indo-West Pacific region. Mem. Qd Mus. 31: $337-348$

Staples, D. J., Heales, D. S. (1991). Temperature and salinity optima for growth and survival of juvenile banana prawns Penaeus merguiensis. J. exp. mar. Biol. Ecol. 154: 251-274

Staples, D. J., Vance, D. J. (1986). Emigration of juvenile banana prawns Penaeus merguiensis from a mangrove estuary and recruitment to offshore areas in the wet-dry tropics of the Gulf of Carpentaria, Australia. Mar. Ecol. Prog. Ser. 27: 239-252

Staples, D. J., Vance, D. J., Heales, D. S. (1985). Habitat requirements of juvenile penaeid prawns and their relationship to offshore fisheries. In: Rothlisberg, P. C., Hill, B. J., Staples, D. J. (eds.) Second Australian National Prawn Seminar. NPS2, Cleveland, Australia, p. 47-54

Turmbull, C. T., Mellors, J. E. (1990). Settlement of juvenile Penaeus esculentus (Haswell, 1879) on nursery grounds in Torres Strait. In: Mellors, J. E. (ed.) Torres Strait Prawn Project: a review of research 1986-88. Queensland Department of Primary Industries Fisheries Branch information series Q190018, p. 29-37

UNESCO (1988). IOC-FAO workshop on recruitment of penaeid prawns in the Indo-West Pacific region (PREP). IOC workshop report No. 56

White, T. F. C. (1975). Population dynamics of the tiger prawn Penaeus esculentus in the Exmouth Gulf prawn fishery and implications for the management of the fishery. Ph.D. thesis, University of Western Australia, Perth

Williams, L. (1991). Moreton Bay a productive fishery. The Queensland Fisherman 9 (4): 23-26

Young, P. C. (1977). A working key to the common species of juvenile penaeid prawns from Moreton Bay, Queensland, Australia (Penaeidae: Natantia). CSIRO, Division of Fisheries and Oceanography, Report 72

Young, P. C. (1978). Moreton Bay, Queensland: a nursery area for juvenile penaeid prawns. Aust. J mar. Freshwat. Res. 29: $55-75$

Young, P. C., Carpenter, S. M. (1977). Recruitment of postlarval penaeid prawns to nursery areas in Moreton Bay, Queensland. Aust. J. mar. Freshwat. Res. 28: 745-773

Zein-Eldin, Z. P., Griffith, G. W. (1969). An appraisal of the effects of salinity and temperature on growth and survival of postlarval penaeids. FAO Fish. Rep. 57(3) : 1015-1026

Zimmerman, R. J., Minello, T. J., Zamora, G. Jr (1984). Selection of vegetated habitat by brown shrimp. Penaeus aztecus, in a Galveston Bay salt marsh. Fish. Bull. U.S. 82 $325-336$

Manuscript first received: December 14, 1992

Revised version accepted: October 29, 1993 